\title{
Eynan (Ain Mallaha)
}

FRANÇOIS R. VALlA, H. KHALAILY, N. SAMUELIAN, F. BOCQUENTIN, A. BRIDAULT, and R. RABINOVICH

\subsection{INTRODUCTION}

The site of Eynan (Ain Mallaha) attracted prehistoric people because of the variety and availability of resources provided by the slopes of the Upper Galilee, the marginal marshes and shores of Lake Hula, a species-rich and abundant perennial spring, and the banks of a rivulet between the spring and the lake (Fig. 34.1). The archaeological deposits were excavated during three sessions between 1955-1961 under J. Perrot, then 1972-1976 under J. Perrot, M. Lechevallier, and F. Valla, and 1996-2005 under F. Valla and H. Khalaily. Human visitors are attested during the Middle Palaeolithic and again during the Early Epipalaeolithic. Later, during the Natufian period, the site was one of the main human settlements in the Levant, intermittently inhabited for several millennia during the Early, Late, and Final phases of the period. Radiocarbon ages indicate an approximate age of $14,326 \pm 266 \mathrm{cal}$ BP for the Early Natufian occupation, whereas the Final Natufian layer is $12,466 \pm 179$ and $11,895 \pm 141 \mathrm{cal} \mathrm{BP}$ in the lower and top parts, respectively (Perrot 1966; Valla et al. 2007).

\subsection{THE BUILDINGS AND GRAVES OF EYNAN}

A hamlet of semi-buried buildings was constructed south of the spring. The extension of the settlement and the number of contemporaneous buildings are difficult to extrapolate from the 200-250 $\mathrm{m}^{2}$ area currently excavated. In this area, the buildings take advantage of a slope overlooking the spring. They are delimited by circular or semi-circular walls, sometimes still standing more than $1 \mathrm{~m}$ high, which served as retaining walls. Their size tends to decrease with time. The oldest, from the Early Natufian phase, attain up to $7 \mathrm{~m}$ in diameter. The diameter of those from the Final Natufian phase is $\leq 3.5 \mathrm{~m}$. The walls are composed of a facing of raw limestone blocks applied against the vertical surface created by cutting into the slope. Instead of a stonewall, one of the Early Natufian houses was coated with a red-painted lime plaster, which is among the oldest evidence for sophisticated pyrotechnical processes in the
Near East. While there are few indications of roofing, some buildings have post-holes. The most elaborate of them is from the Early Natufian phase. It was partially destroyed but still preserves the setting of seven posts arranged in two lines, one straight, the other curved (Fig. 34.2A). According to pollen and phytolith remains, some superstructures may have been made with reeds (Phragmites sp.). Each building has at least one hearth, most of them built from stone. Floors were identified thanks to these small installations, sometimes associated with partial pavements of slabs or pebbles. These indications could be combined with those provided by ash dispersals from the hearths, and by objects lying flat, to reconstruct coherent surfaces. Several buildings display more than one of these floors superimposed, sometimes linked to repairs of at least part of the wall.

Field observations indicate that some floors could be compatible with a function as a house, while others were not. Further analyses of the finds apparently support this inference. House floors attest to a broad range of activities not matched by the other floors. The best case studies, from the Final Natufian phase, indicate oval houses limited southward (upslope) by a wall associated with a row of small constructions (hearths, post-holes, etc.) between its two ends, separating two spaces. Work places are indicated by concentrations of flint debris. They seem to be related to large stones, possible seats, and are mainly in the outer (northern) half of the building (Fig. 34.2B). In contrast, the floors not intended for dwelling are not divided. The activities, generally, seem to be centred around one or more hearths, each of different shape. It is worth mentioning that the same building can change functions on successive floors (Samuelian 2013).

During the Early Natufian, houses were associated with graves either under floors or in fills. Most corpses were buried individually and flexed on the side, back, or even face, some of them with body ornaments made mainly of Dentalium shells and bone beads. Stones were sometimes added on or around the corpse to maintain it in a desired position (Fig. 34.3A). One interment included a puppy with an old woman (Fig. 34.3B). Both sexes and all ages, from newborn to elderly, are present in the available sample, which is too small to 


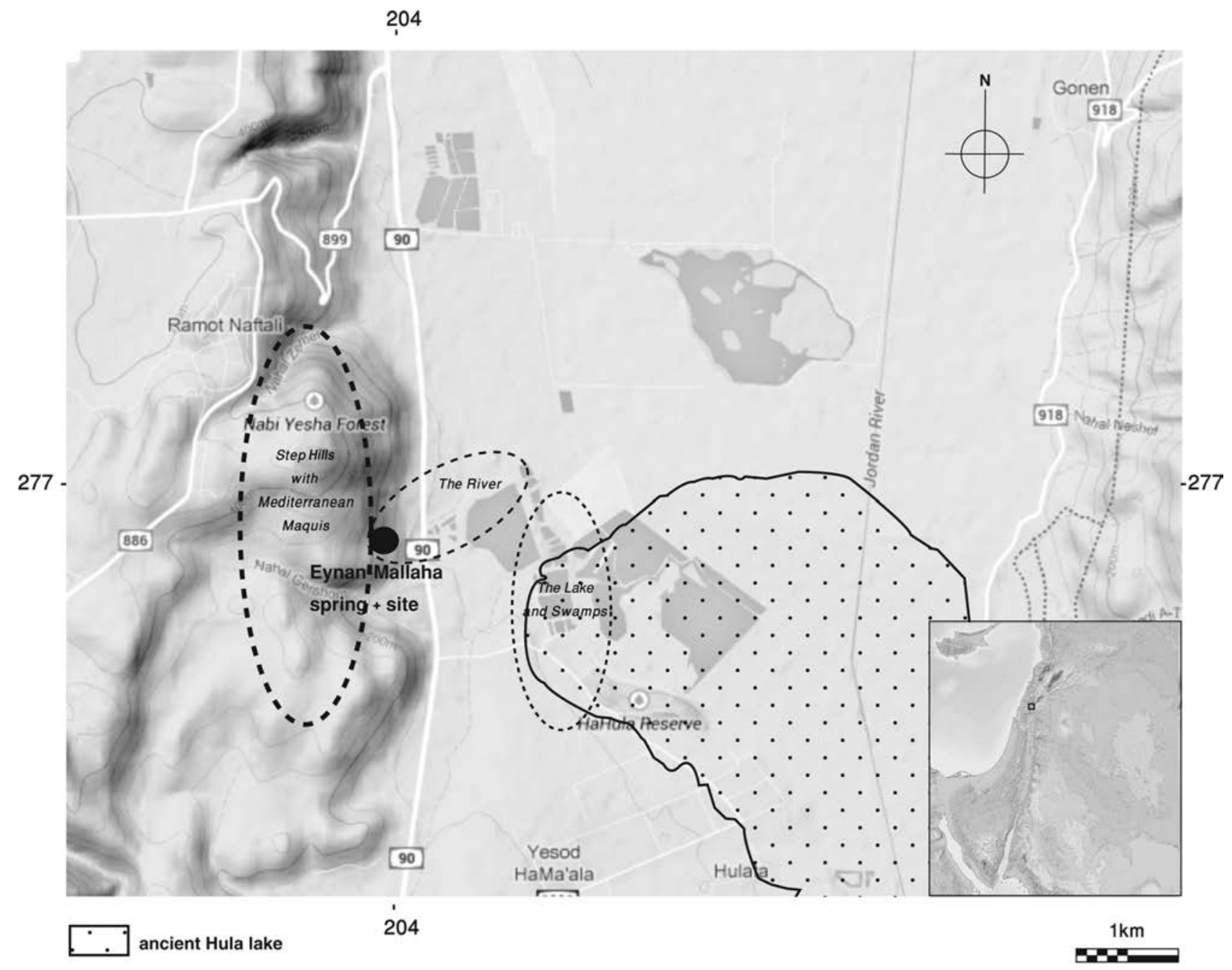

Figure 34.1 Topographic map of the Hula Basin near the spring of Eynan-Ain Mallaha, with indications of the main natural ecological niches.

validate possible selections against young children and/or women. Hypoplasia found on some skeletons indicates dietary deficiency or infectious diseases during childhood. Dental caries does occur. Traces of trauma on the bones may reveal interpersonal violence, but such traces are rare.

The Late Natufian shows a break in funerary customs. Many deep or shallow pits, some of them coated, were dug along with the buildings. According to the evidence at hand, they were mainly for trash disposal and burials. Most skeletons were found in those pits (Fig. 34.3C), some disturbed by up to 11 interments, most of them successive. Decorated corpses disappear, but two skulls may have borne gazelle horn cores attached to them. Large stones were sometimes added in or on the pits. A selection in favour of males becomes more obvious, and no newborns were uncovered. Hypoplasia and caries diminish.

During the Final Natufian, traditional habits return and graves are connected to house floors. Typically, they accommodate individual bodies narrowly contracted in various positions and devoid of any ornaments (Fig. 34.3D). No selection according to age or sex can be discerned. Hypoplasia is even rarer, but caries is at its highest.
For the first time at the site, a few individuals attest to removal of the central right upper incisor.

The inhabitants of Eynan-Ain Mallaha share most of their physical characteristics with other Natufian populations. Nevertheless, they have somewhat more robust upper limbs, especially the males. A relatively high occurrence of caries may be related to a diet richer in vegetal food (Bocquentin 2003).

Stratigraphy, ages, buildings, and graves all indicate three welldifferentiated stages of occupation at Eynan-Ain Mallaha. The associated finds support this subdivision.

\subsection{ARTEFACTS}

Huge quantities of flint were recovered from each phase. They attest to a variety of raw materials, primarily good quality flint from the nearby environment. Only the debitage of the Early Natufian was thoroughly analysed. The technique was relatively simple, producing flakelets, bladelets of two different sizes, and flakes. Blades do occur as a target but are relatively rare. These blanks could be used 

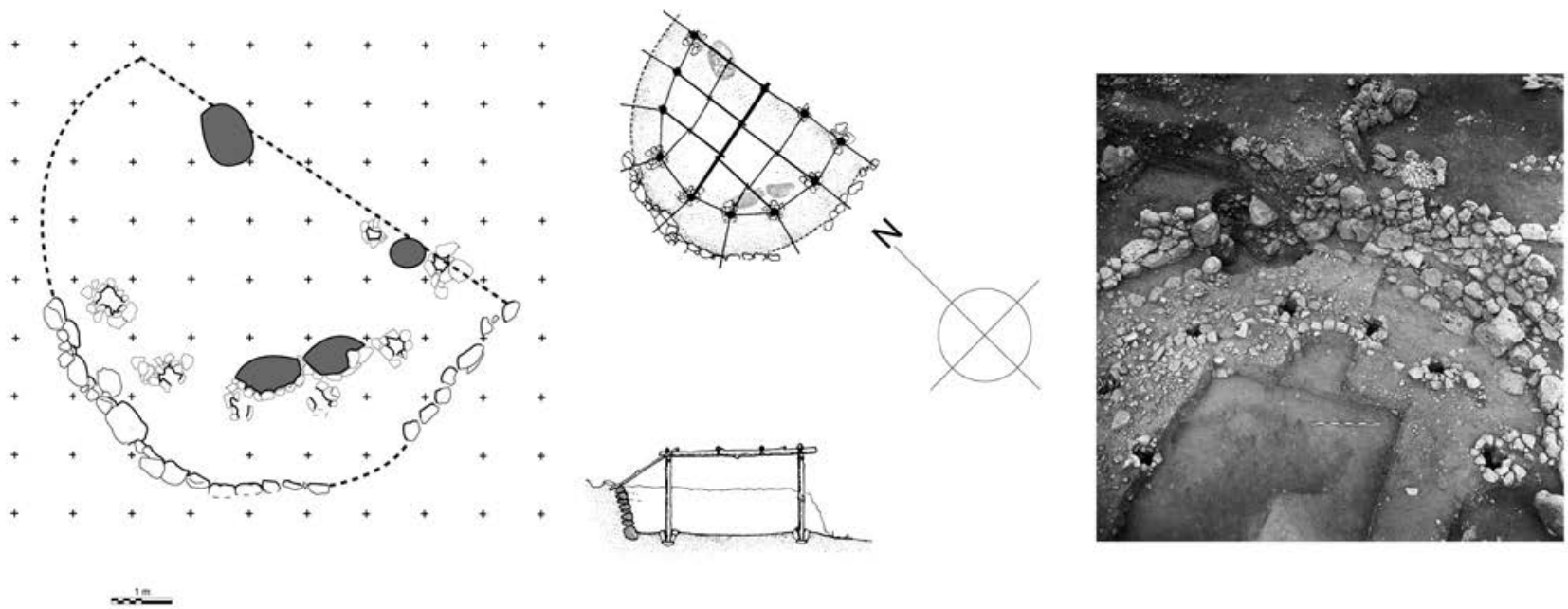

A
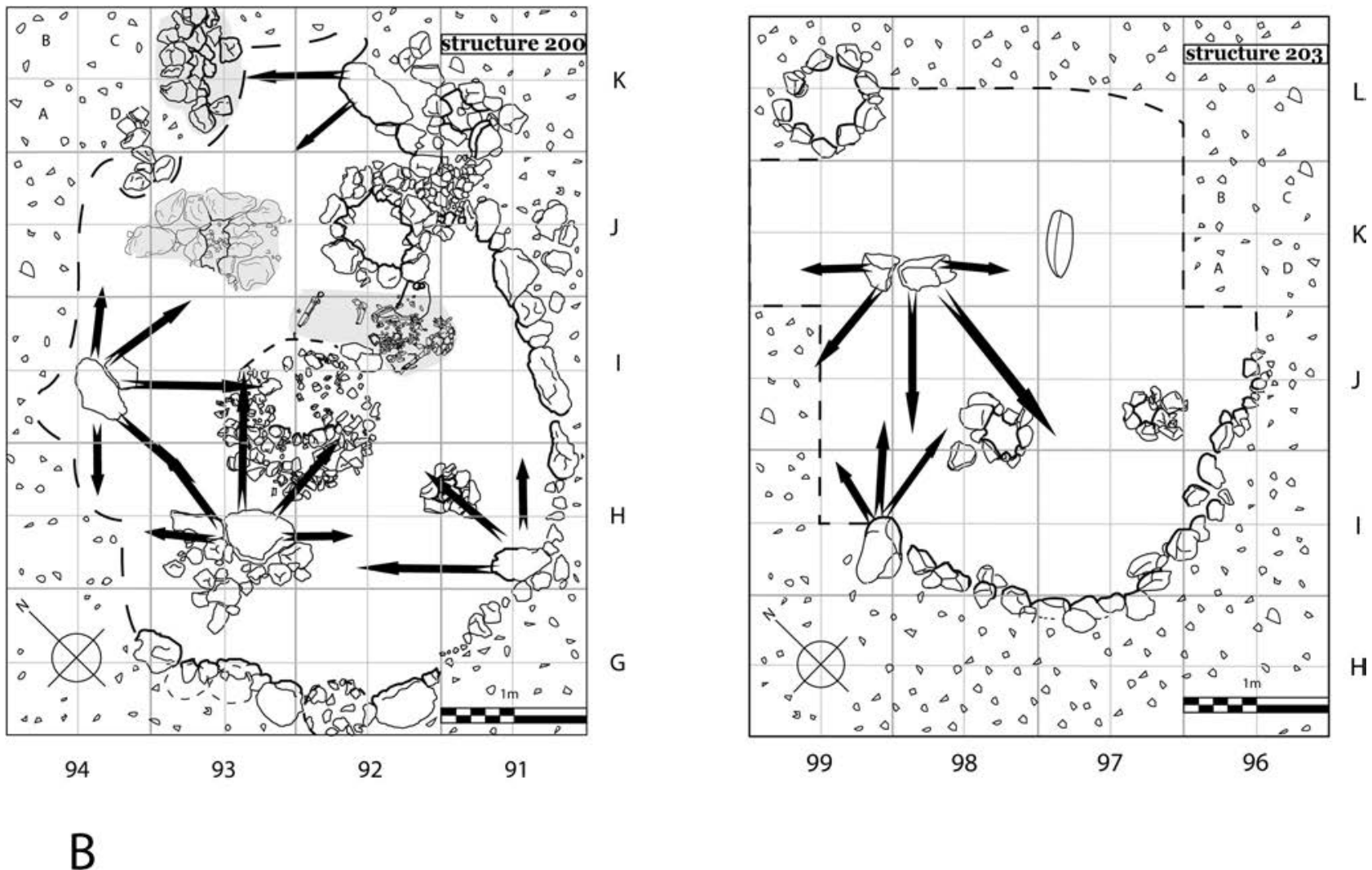

B

\section{artefact diffusion flow from the workstations}

Figure 34.2 Eynan buildings: the 'houses'. A: Schematic map, tentative reconstruction and photographic view of house 131 (Early Natufian) (after Valla 1988); B: main knapping locations as suggested by objects distributed on the floors of houses 200 and 203 (Final Natufian) (after Samuelian 2013). 

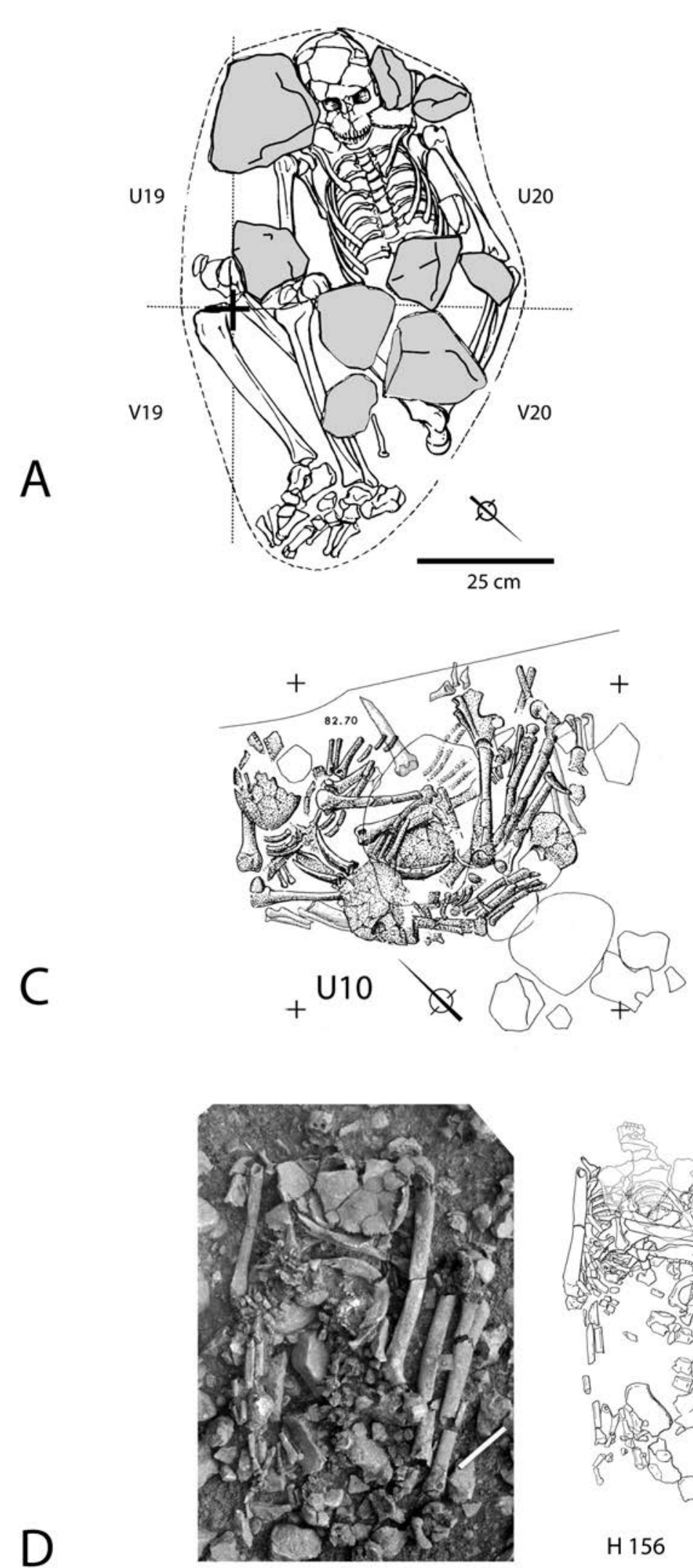
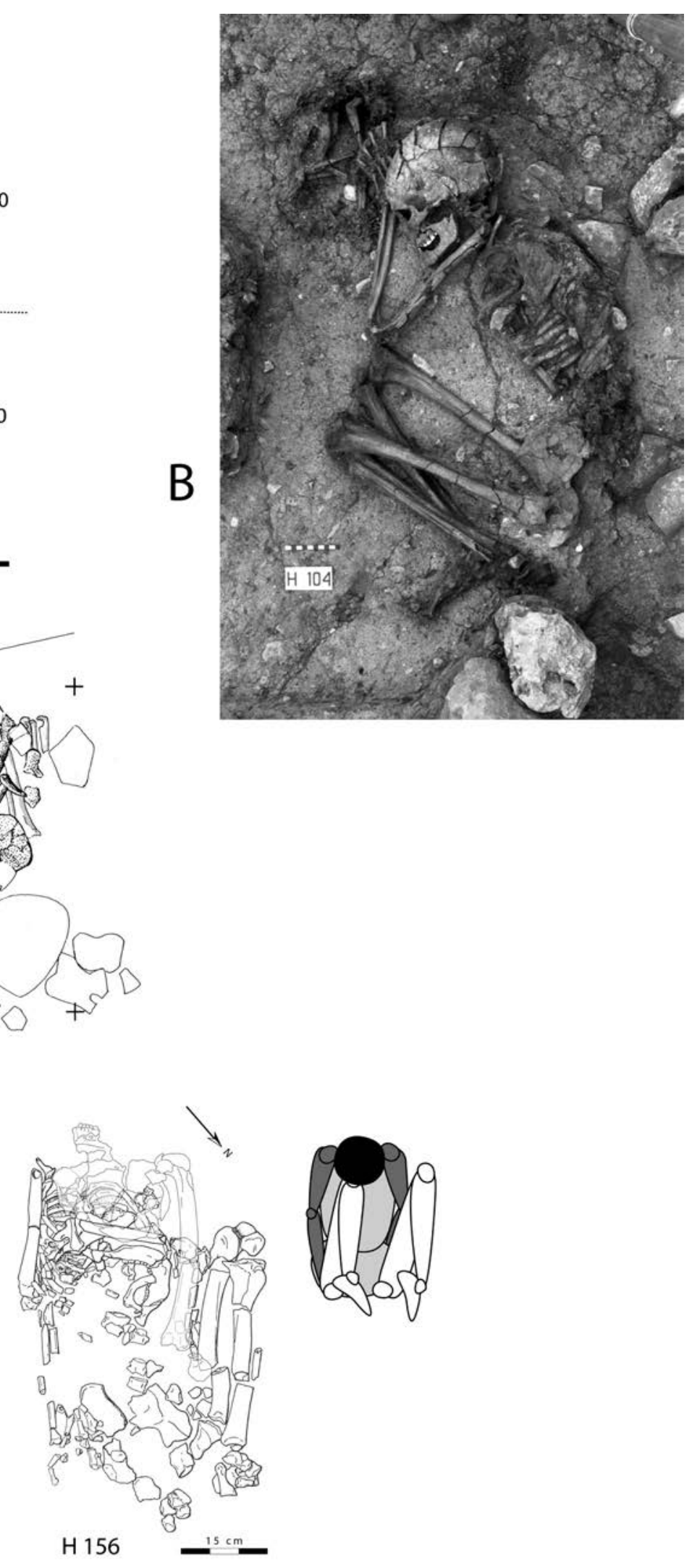

Figure 34.3 Eynan graves. A: Early Natufian H.15 lying on his back with stones on and around the corpse (Archives of Mallaha excavations); B: Early Natufian H.104: an elderly woman buried with a puppy, probably in relation to house 131 (after Davis \& Valla 1978); C: Late Natufian pit containing several bodies successively introduced (Grave H.10) (Archives of Mallaha excavations); D: Final Natufian H.156: an adult woman laid on a floor of house 203. The highest parts of the body were disturbed when the house was occupied anew (after Bocquentin et al. 2013). 
without modification (many flakelets) or shaped into formal tools by retouch. During all three phases, the same types of tools were shaped in approximately similar proportions: half of them were microliths, of which lunates were only a minor component. However, these lunates, the hallmark of the Natufian culture, underwent characteristic changes from one phase to the other. The typical bifacial Helwan retouch was gradually replaced by an abrupt mode of shaping, and the objects became increasingly smaller (Fig. 34.4A). These modifications are all the more remarkable in that the smaller lunates, those from the Final Natufian, are the most difficult to produce, whereas the function of the instrument, as hunting weapon armatures, did not change (Valentin et al. 2013).

Flint aside, basalt was the stone most commonly worked into tools. It could be found a few kilometres away, either in river beds or in primary context to the west (Dalton and Alma Plateaus), south (Khorazim saddle), and east (Golan Heights) (Horowitz 1979). Pounding and grinding implements, namely deep mortars (Fig. 34.4B), pestles, grinding slabs (Fig. 34.4B), and handstones dominate the assemblage; it is difficult to apprehend their economic role. In contrast to the expediently made and briefly used flint tools, the basalt tools demonstrate a high degree of workmanship and were cared for. Moreover, they had a variety of functions, as is demonstrated by their diverse sizes (e.g. height of mortars is $12-60 \mathrm{~cm}$ ). It seems that the flat grinding instruments become proportionally more abundant in the Final Natufian. Some of them are stained with ochre. Use-wear analyses show that large 'saddle querns' were used to process legumes throughout the entire sequence (Dubreuil 2004). One of those querns was still at its working place in a Final Natufian house.

\subsection{USE OF FAUNAL AND FLORAL REMAINS}

Faunal remains are extremely abundant and diverse but heavily broken and incrusted. Methodological aspects need to be further expanded to construct an approximate image of the role played by the different species in the diet. Nonetheless, the location of the site between various productive niches was exploited with an emphasis on humid habitats, resulting in a 'broad spectrum economy' (Flannery 1969). The occupants of Eynan-Ain Mallaha took advantage of mammals, micromammals, birds, chelonia, reptiles, amphibians, crustaceans, fish, and molluscs where they were available. Compared with other Natufian sites, gazelles are significantly less dominant among ungulates, and the contribution of wild boar is higher. Hares may be linked to new trapping techniques, and foxes are interpreted as evidence for the creation of new environments around long-term occupied villages (Bridault et al. 2008).

Osseous materials were worked on a limited scale compared with flint. A large range of species was used, including small mammals and birds. Long bones (mainly metapodials), phalanges, and ribs were preferentially selected. Cervid antlers were less favoured. The bones were heavily modified through a broad variety of techniques, including abrasion and heating, during the entire sequence. Most implements were points of various shapes and sizes, some of them very small. Many were intended to be hand-held. Others are project- ile points. Bone sickles, an emblematic Natufian tool, were found in every phase, albeit rarely. Curved 'hooks' appear regularly in the Final phase. At the current stage of research, the main change clearly attested from one phase to another is a reduction in the production of the 'retoucher', a bone splinter intended to retouch flint tools.

Bones were also modified into body ornaments. The necklaces, bracelets, and other items found in the Early Natufian graves were composed of a combination of bone beads and pendants with shells, mainly Dentalia from the Mediterranean Sea (Fig. 34.4C). The characteristic bead is a sawn extremity of a gazelle phalange. Other shapes, which are dominant in nearby settlements, are less frequent or rare. They may attest to contact with foreign groups. Bone ornaments are almost absent from the Late Natufian layers, perhaps owing to recovery bias, but Dentalia are also rare. In the Final Natufian layer all the locally traditional elements appear, but are now dispersed in the fill. Despite the conservative attitude usually associated with body decorations some changes can be detected. Dentalium shells are cut into smaller segments (Le Dosseur \& Maréchal 2013). Stones valued for their colour (green, red, black, white) become a regular constituent, maybe under northern influence.

Little is known of plant use during the Early Natufian phase. Emphasis seems to be on the exploitation of woody environments, which is confirmed by the recovery of fragments of almonds and pistachios. Phytolith studies indicate an interest shift during the Final Natufian toward exploiting more humid areas. Reeds probably supplied raw materials for mats and sedges for basketry. Millet was probably collected for food. There are also indications for an increased consumption of annuals from drylands, but small-seeded grasses are more abundant than barley and wheat, which appear in few samples only, probably because it had to be gathered about 12$16 \mathrm{~km}$ south of the site (Rosen 2013).

Besides body ornaments, only scarce indications of the way of thinking were found. Only a few tools (stone and bone) are decorated. A handful of figurines do appear. Some are interpreted as schematic human representations. Others are inspired by the animal world (Fig. 34.4D). A few pebbles bear thin engravings of patterns also known from other sites (ladder-like, zigzag). Nevertheless, elaborate and comprehensive thinking is manifested by a complex system of buildings and grave orientations according to the cardinal points. A probable myth underlying the recurrent associations of objects such as stones, human remains, and dog, gazelle, and tortoise bones can also be suspected.

\subsection{SUMMARY}

Eynan (Ain Mallaha) is uniquely significant in the history of prehistoric research in Israel and beyond because it was the site where Natufian architecture was identified for the first time in 1955. Together with the large number of graves, the heavy basalt pounding tools, as well as the wealth of resources available in its and nearby environmental settings, this finding led to the conclusion that the Eynan people were able to experiment with a sedentary way of life. As a result, it became clear that, in the Near East, sedentism was 
F.R. Valla et al.
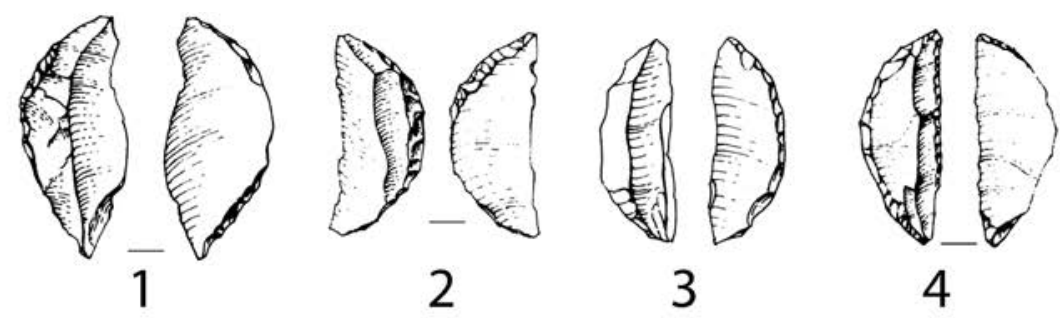

A
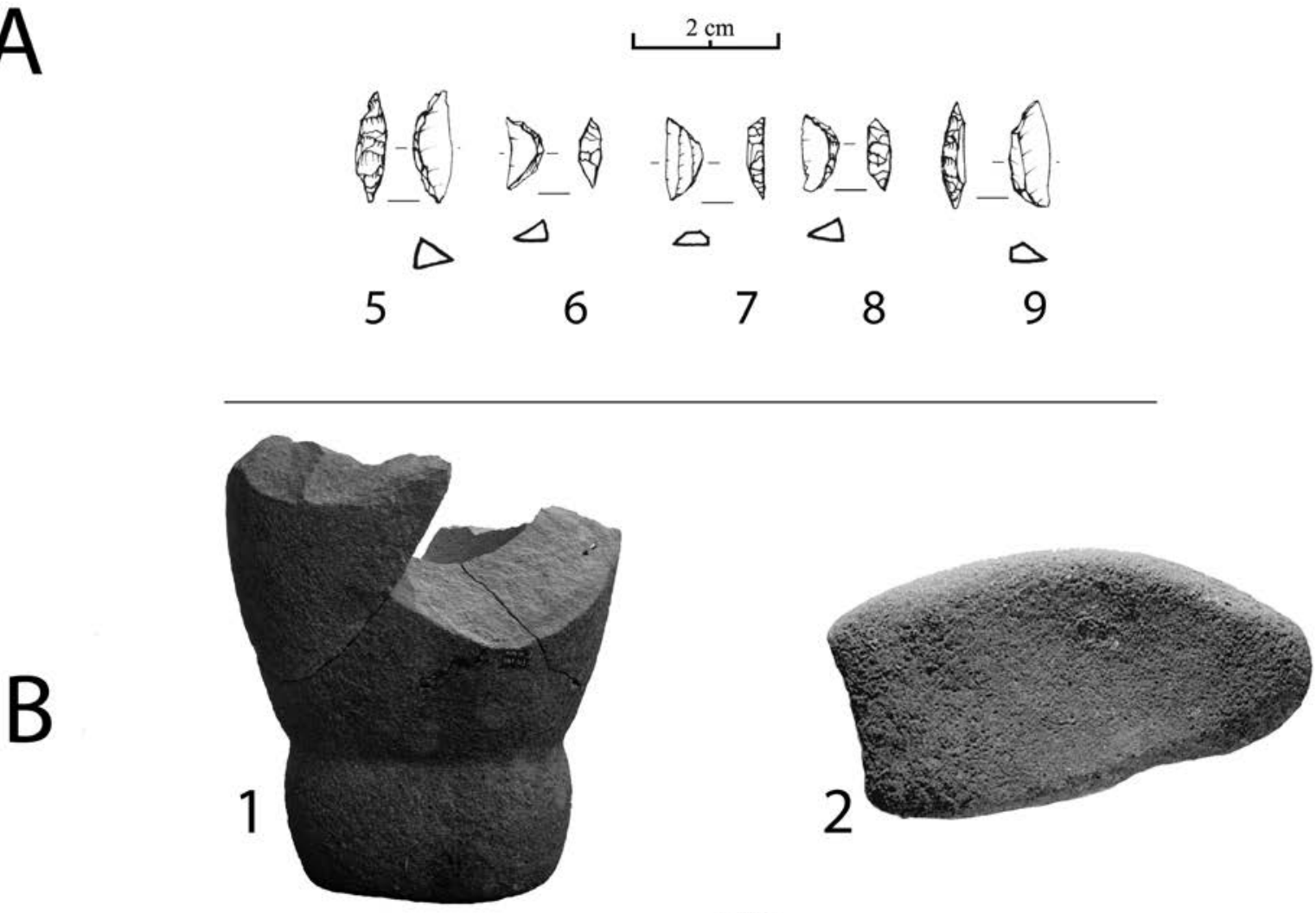

\section{$\widetilde{5 \mathrm{~cm}}$}

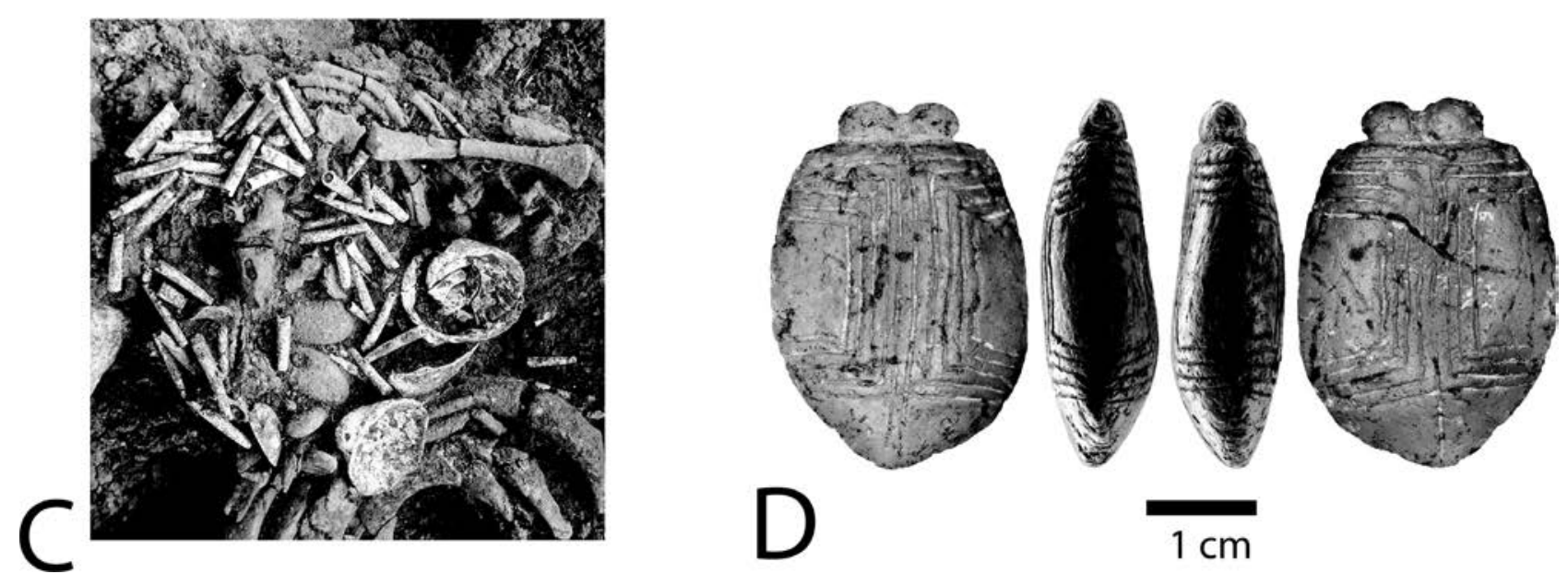

Figure 34.4 Eynan human workmanship: some examples. A: Early Natufian (1-4) compared to Final Natufian (5-9) lunates, after Valentin in Valla et al. (2007). B: 1, Basalt mortar (Early Natufian); 2, basalt grinding stone (Final Natufian) (1 unpublished, 2 after Samuelian 2013, photo M. Barazani). C: Necklace under the skull of newborn H.176 (Early Natufian) (after Bocquentin and Cabellos in Valla et al. 2007). D: A rare Early Natufian animal figurine from House 131 (photo by L. Davin). 
a precondition for experiments that were to drive people to grow plants, and not the other way around, as was then accepted. This laid the groundwork for the development of our present model for the beginning of agriculture. According to the new understanding, as early as the end of the Pleistocene, some hunting, fishing, collecting, and gathering societies were able to sustain a more or less sedentary way of life in permanent precursors of villages where the social feasibility for sowing cereals and legumes in artificially prepared fields matured, a development that was to happen later.

Further excavations uncovered a long stratigraphic sequence reminiscent of that seen elsewhere by D. Garrod and R. Neuville. A differentiation among the buildings was observed, some of them assuming the functions later fulfilled by houses (expressions of the division of the society, symbolic representations of the world, contexts for technical activities) while others did not. It confirmed the stability of both the group and the hamlet during the Natufian period. It was also shown that, despite somewhat cooler average temperatures (see Mienis in Valla et al. 2007), the ecological habitats in the Hula basin during the Younger Dryas were not very different from recent times (Ashkenazi 2013). Throughout the entire sequence, few objects were brought to the site that could not be collected nearby. The relatively large number of Cappadocian obsidian pieces found in the Final Natufian layer illustrates intensifying ties with northern groups, probably significantly broadening the social network in the Near East. From that moment, exchanges were never severed between the southern and the northern Levant.

\section{REFERENCES}

Ashkenazi, S. 2013. Reconstruction of the ecosystem of the Final Natufian site of Ain Mallaha (Eynan). In Natufian Foragers in the Levant, ed. O. Bar-Yosef \& F.R. Valla. Ann Arbor: International Monographs in Prehistory, pp. 312-18.

Bocquentin, F. 2003. Pratiques funéraires, paramètres biologiques et identités culturelles au Natoufien: une analyse archéo-anthropologique. Unpublished Ph.D. thesis, Université Bordeaux 1.
Bocquentin, F., Cabellos, T. \& Samuelian, N. 2013. Graves in context: field anthropology and the investigation of interstratified floors and burials. In Natufian Foragers in the Levant, ed. O. Bar-Yosef \& F.R. Valla. Ann Arbor: International Monographs in Prehistory, pp. 18592.

Bridault, A., Rabinovich, R. \& Simmons, T. 2008. Human activities, site location and taphonomic process: A relevant combination for understanding the fauna of Eynan (Ain Mallaha), level IB (Final Natufian), Israel. Archaeozoology of the Near East VIII, ed. E. Vila, L. Gourichon, A. Choyke \& H. Buitenhuis. Lyon: Maison de l'Orient méditerranéen, pp. 99-117.

Davis, S.J.M. \& Valla F.R. 1978. Evidence for domestication of the dog 12,000 years ago in the Natufian of Israel. Nature 276: 608-10.

Dubreuil, L. 2004. Long-term trends in Natufian subsistence: A use-wear analysis of ground stone tools. Journal of Archaeological Science 31: $1613-29$.

Flannery, K.V. 1969. Origins and ecological effects of early domestication in Iran and the Near East. In The Domestication and Exploitation of Plants and Animals, eds. P.J. Ucko \& G.W. Dimbleby. London: Duckworth, pp. 73-100.

Horowitz, H., 1979. The Quaternary of Israel. New York: Academic Press. Le Dosseur, G. \& Maréchal, C. 2013. Bone ornamental elements and decorated objects of the Natufian from Mallaha. In Natufian Foragers in the Levant, ed. O. Bar-Yosef \& F.R. Valla. Ann Arbor: International Monographs in Prehistory, pp. 293-311.

Perrot, J. 1966. Le gisement natoufien de Mallaha (Eynan), Israël. L'Anthropologie 70: 437-83.

Rosen, A.M. 2013. Natufian foragers and the monocot revolution: A phytolith perspective. In Natufian Foragers in the Levant, ed. O. BarYosef \& F.R. Valla. Ann Arbor: International Monographs in Prehistory, pp. 638-48.

Samuelian, N. 2013. Les chasseurs et cueilleurs du Natoufien final d'Ain Mallaha (Eynan), Israël: la structuration spatiale et fonctionnelle de leur habitat. Unpublished Ph.D. thesis, Université Paris 1.

Valentin, B., Valla, F.R. \& Plisson, H. 2013. Flint knapping and its objectives in the Early Natufian: The example of Eynan-Ain Mallaha (Israel). In Natufian Foragers in the Levant, ed. O. Bar-Yosef \& F.R. Valla. Ann Arbor: International Monographs in Prehistory, pp. 203-26.

Valla, F.R. 1988. Aspects du sol de l'abri 131 de Mallaha (Eynan), Paléorient 14/2: 283-96.

Valla, F.R., Khalaily, H., Valladas, H. et al. 2007. Les fouilles de Ain Mallaha (Eynan) de 2003 à 2005: Quatrième rapport préliminaire. Journal of the Israel Prehistoric Society - Mitekufat Haeven 37: 135-379. 
